\title{
PENGARUH MODEL PEMBELAJARAN INKUIRI TERBIMBING TERHADAP HASIL BELAJAR SISWAPADAMATERIPOKOK LISTRIK DINAMISKELAS X SEMESTER II SMA NEGERI 14 MEDANT.P 2014/2015
}

\author{
Denny Khairani dan Winsyahputra Ritonga \\ Jurusan Fisika FMIPA Universitas Negeri Medan \\ denykhairani@yahoo.co.id
}

\begin{abstract}
ABSTRAK
Telah dilakukan penelitian yang bertujuan untuk mengetahui pengaruh model pembelajaran inkuiri terbimbing terhadap hasil belajar fisikapada materi listrik dinamis di SMA Negeri 14 Medan.Jenis penelitian ini adalah quasi eksperimen. Populasi dalam penelitianadalah seluruh siswa kelas Xyang terdiri dari 9 kelas.Sampel penelitian ini adalah siswa kelasX-1 sebagai kelas eksperimen dan kelas X-5 sebagai kelas kontrol. Hasil penelitian menunjukkan nilai rata-rata postes kelas eksperimen 65,00 dan kelas kontrol 57,94. Hasil uji t satu pihak diperoleh $t_{\text {hitung }}=2,39 \mathrm{dan} \mathrm{t}_{\text {tabel }}=1,67$, sehingga $\mathrm{t}_{\text {hitung }}>\mathrm{t}_{\text {tabel }}$ maka disimpulkan bahwa ada perbedaan akibat pengaruh model pembelajaran inkuiri terbimbing terhadap hasil belajar siswa pada materi pokok Listrik Dinamis di kelas X.
\end{abstract}

Kata kunci :model pembelajaran, inkuiri terbimbing, hasil belajar fisika.

\begin{abstract}
Has been done research aim to determine the effect of guided inquiry learning model on learning physics outcomes on dynamic electric material at SMA Negeri 14 medan. The type of this research was quasi experiment. Theresearch population was all students at class $X$ consist of 9 classes. The sample of this research were students of class $X-1$ as experiment class and class $X-5$ as control class. The results showed that post test average velue in experiment class was 65,00 and in control class was 57,94. One party $t$-test result showed that tount was 2,39 and table was 1,67, so tcount $>t_{\text {table }}$ it can be concluded that there was differences because of the effect of guided inquiry learning model on students learning outcomes on dynamic electric material at class $X$.
\end{abstract}

Keywords : learning model, guided inquiry, physics learning outcomes.

\section{PENDAHULUAN}

Segala macam upaya dilakukan untuk perbaikan dalam pengajaran di sekolah terlebih untuk mata pelajaran fisika dewasa ini.Yang diperbaiki dan diperbaharui adalah sistem pendidikan yaitu berupa perubahan kurikulum, serta perbaikan dalam hal kompetensi pengajar.Namun jarang bertitik tolak pada kesulitan memahami konsep pelajaran yang dialami siswa sebagai obyek pendidikan (Sudibyo dan Supardi, 2013:38). Untuk memperbaiki pemahaman siswa, terlebih dahulu harus mengetahui kesulitan-kesulitan yang dialami oleh siswa tersebut.Kesulitan-kesulitan tersebut dapat berupa kesulitan memahami materi, menerapkan konsep, menafsirkan maksud soal, dan mengingat rumus.

Hasil studi pendahuluan yang dilakukan peneliti menunjukkan sebagian besar siswa tidak menyukai pelajaran fisika dan menganggap pelajaran fisika sulit dan membosankan serta pembelajaran di dalam kelas hanya berlangsung dengan kegiatan 
mencatat, mendengarkan penjelasan guru, mengerjakan soal serta pembagian tugas dan latihan. Adanya keterbatasan penyediaan alat-alat laboratorium di sekolah membuat guru sulit untuk menciptakan pembelajaran yang menarik dan menyenangkan. Namun, peneliti berpendapat bahwa masalahnya tidak hanya mengenai kurangnya fasilitas yang disediakan sekolah, namun lebih kepada kurangnya rasa ingin tahu, minat dan perhatian siswa dalam belajar khususnya fisika serta tidak percaya diri, mudah putus asa dalam belajar.

Berdasarkan hasil studi pendahuluan menggunakan angket dan wawancara dapat disimpulkan bahwa proses pembelajaran tidak berpusat pada siswa, yang mengakibatkan siswa berperan tidak aktif dalam memperoleh pengetahuan. Siswa kurang motivasi dalam belajar sehingga siswa tidak bersemangat dan dalam pembelajaran siswa bersifat menjadi pendengar saja dan guru yang bersifat dominan (teacher centered). Dominasi guru dalam pembelajaran ini menyebabkan siswa lebih banyak menunggu sajian dari guru daripada menemukan sendiri. Oleh karena itu, untuk mengatasi hal tersebut perlu digunakan suatu model pembelajaran yang berpusat pada siswa.

Berdasarkan masalah di atas, salah satu model pembelajaran yang dapat digunakan adalah model pembelajaran inkuiri terbimbing. Inkuiri terbimbing adalah cara berpikir, belajar dan mengajar yang mengubah budaya sekolah menjadi sebuah komunitas penyelidikan yang kolaboratif. Inkuiri terbimbing adalah model yang fleksibel yang membantu guru untuk memandu siswa melalui alur penemuan dalam proses belajar dari berbagai sumber informasi untuk mempersiapkan peserta didik berhasil dalam pembelajaran dan hidup di era informasi (Kuhlthau, dkk, 2012:10).
Selain itu, menurut Yunus, dkk (2013:49), pada model pembelajaran inkuiri, guru harus merancang pembelajaran inkuiri yang melibatkan siswa secara aktif. Pada proses awal pembelajaran guru memberikan banyak bimbingan kemudian secara teratur mengurangi frekuensi bimbingan dengan demikian siswa dapat menjadi penyelidik yang baik dan pengetahuan ilmiahnya dapat terpenuhi. Dengan menggunakan model pembelajaran inkuiridiharapkan proses pembelajaran merupakan proses memperoleh konsep dari keterlibatan siswa secara langsung dan mampu meningkatkan hasil belajar siswa.

Siswa akan mendapatkan pemahaman-pemahaman yang lebih baik mengenai fisika dan akan lebih tertarik dan termotivasi belajar fisika jika siswa dilibatkan secara aktif dalam pembelajaran. Hal itu sejalan dengan pernyataan Kuhlthau, dkk (2007:6) inkuiri terbimbing menciptakan lingkungan yang memotivasi siswa untuk belajar dengan memberikan kesempatan bagi mereka untuk membangun makna mereka sendiri dan mengembangkan pemahaman yang mendalam. Pembelajaran inkuiri terbimbing dapat mengembangkan cara berpikir ilmiah yang menempatkan siswa sebagai pembelajar dalam memecahkan permasalahan dan memperoleh pengetahuan yang bersifat penyelidikan sehingga dapat memahami konsep sains. Suchman dalam Hosnan (2014:345) juga menyatakan inkuiri terbimbing bertujuan agar pembelajar dapat belajar secara mandiri, membantunya dalam membangun pengetahuan dan keterampilan bertanya dan mencari jawaban berdasarkan rasa ketertarikan dan ingin tahunya. Dengan kata lain, pembelajaran inkuri terbimbing mampu mengembangkan keinginan dan motivasi siswa untuk mempelajari 
prinsip dan konsep fisika (Kurniawati, dkk, 2014:37).

Berdasarkan permasalahan diatas maka penulis ingin menggunakan model inkuiri terbimbing dalam kegiatan belajar mengajar. Pembelajaran dengan model inkuiri terbimbing salah satu bentuk kegiatan dalam pembelajaran yang dapat mengaktifkan siswa, mengembangkan keterampilan siswa dalam penyelidikan serta menciptakan lingkungan yang memotivasi siswa untuk belajar.

\section{METODOLOGI PENELITIAN}

Penelitian ini dilakukan di SMA Negeri 14 Medan pada bulan April sampai Mei 2015. Populasi dalam penelitian adalah seluruh siswa kelas $\mathrm{X}$ SMA Negeri 14 Medan T.P 2014/2015 yang terdiri atas 9 kelas.Pengambilan sampel dilakukan dengan teknik pengambilan sampel acak berkelompok (cluster random sampling), diambil 2 kelas yaitu kelas X-1sebagai kelas eksperimen diajarkan model inkuiri terbimbing dan kelas X-5 sebagai kelas kontrol diajarkan dengan pembelajaran konvensional.

Jenis penelitian quasi experiment. Quasi experiment didefinisikan sebagai eskperimen yang memiliki perlakuan, pengukuran dampak unit eksperimen namun tidak menggunakan penugasan acak untuk menciptakan perbandingan dalam rangka menyimpulkan perubahan yang disebabkan perlakuan (Cook \& Campbell dalam Wicaksono, dkk, 2011:1).

Desain penelitian ini adalah noneqivalent control group design atau Nonrandomized Control Group, Pretest-Posttest Design. Desain ini mirip dengan pre-test-posttest di dalam true experiment namun tidak memiliki penugasan acak didalamnya. Desain penelitian ini dapat dilihat pada tabel 1 sebagai berikut.
Tabel 1.Noneqivalent control group

\begin{tabular}{|l|c|c|c|}
\multicolumn{1}{|c|}{ Kelas } & Pretes & $\begin{array}{c}\text { Perlak- } \\
\text { uan }\end{array}$ & Postes \\
\hline eksperimen & $\mathrm{Y}_{1}$ & $\mathrm{X}$ & $\mathrm{Y}_{2}$ \\
\hline Control & $\mathrm{Y}_{1}$ & - & $\mathrm{Y}_{2}$ \\
\hline
\end{tabular}

Keterangan :

$\mathrm{Y}_{1}=$ Pretes diberikan kepada kelas eksperimen dan kelas kontrol sebelum perlakuan

$\mathrm{Y}_{2}=$ Postes diberikan setelah perlakuan pada kelas eksperimen dan kelas kontrol

$\mathrm{X}=$ Pengajaran dengan menerapkan model pembelajaran inkuiri terbimbing.

Dalam penelitian ini pengumpulan data dilakukan dengan beberapa metode yaitu : metode observasi dan metode tes. Instrumen merupakan alat pengambil data untuk mengungkapkan peningkatan hasil belajar dan aktivitas siswa. Instrumen yang dipersiapkan antara lain: perangkat pembelajaran, lembar pengamatan, dan tes pilihan berganda dengan 20 soal dengan 5 pilihan jawaban.

Sebelum data diolah menggunakan uji t satu pihak untuk mengetahui pengaruh model pembelajaran inkuiri terbimbing terlebih dahulu dilakukan penilaian pretes, uji normalitas (uji lilliefors), uji homogenitas (uji F) dan uji kesamaan rata-rata pretes (uji t dua pihak).

\section{HASIL DAN PEMBAHASAN}

Mengenai identifikasi hasil pretest dan posttest, analisis dan pembahasan, uji hipotesis, serta keterlaksanaan model pembelajaran inkuiri terbimbing.

Berdasarkan hasil tes yang telah dilakukan di SMA Negeri 14 Medan diperoleh data pretes untuk kelas eksperimen dengan jumlah siswa 37 
orang memperoleh nilai rata-rata pretes sebesar 42,02dengan nilai tertinggi adalah 60 dan nilai terendah adalah 25. Untuk kelas kontrol dengan jumlah siswa 34 orang memperoleh nilai rata-rata pretes sebesar 39,85dengan nilai tertinggi adalah 55 dan nilai terendah adalah 25. Data yangdiperoleh ditunjukkan pada tabel 2 dibawah ini.

Tabel 2.Data Nilai Pretes Kelas

Eksperimen dan Kelas Kontrol

\begin{tabular}{|c|c|c|c|c|c|}
\hline \multicolumn{3}{|c|}{$\begin{array}{c}\text { Data nilai pretes kelas } \\
\text { eksperimen }\end{array}$} & \multicolumn{3}{|c|}{$\begin{array}{l}\text { Data nilai pretes } \\
\text { kelas kontrol }\end{array}$} \\
\hline Nilai & $\begin{array}{l}\text { Frek } \\
\text { uensi }\end{array}$ & $\begin{array}{c}\text { Rata- } \\
\text { rata }\end{array}$ & Nilai & $\begin{array}{c}\text { Freku } \\
\text { ensi }\end{array}$ & $\begin{array}{l}\text { Rata } \\
\text {-rata }\end{array}$ \\
\hline 25 & 2 & \multirow{8}{*}{42,02} & 25 & 3 & \multirow{8}{*}{$\begin{array}{c}39,8 \\
5\end{array}$} \\
\hline 30 & 3 & & 30 & 6 & \\
\hline 35 & 7 & & 35 & 6 & \\
\hline 40 & 8 & & 40 & 6 & \\
\hline 45 & 7 & & 45 & 4 & \\
\hline 50 & 4 & & 50 & 5 & \\
\hline 55 & 5 & & 55 & 4 & \\
\hline 60 & 1 & & & & \\
\hline Jumlah & 37 & & Jumlal & 34 & \\
\hline
\end{tabular}

Data postes untuk kelas eksperimen dengan jumlah siswa 37 orang memperoleh nilai rata-rata postes sebesar 65,00dengan nilai tertinggi adalah 80 dan nilai terendah adalah 40. Untuk kelas kontrol dengan jumlah siswa 34 orang memperoleh nilai rata-rata pretes sebesar 57,94dengan nilai tertinggi adalah 75 dan nilai terendah adalah 30. Data yang diperoleh ditunjukkan pada tabel3 dibawah ini.

Tabel 3.Data Nilai Postes Kelas

Eksperimen dan Kelas Kontrol

\begin{tabular}{|c|c|c|c|c|c|}
\hline \multicolumn{3}{|c|}{$\begin{array}{l}\text { Data nilai postes } \\
\text { kelas eksperimen }\end{array}$} & \multicolumn{3}{|c|}{$\begin{array}{c}\text { Data nilai postes kelas } \\
\text { Kontrol }\end{array}$} \\
\hline Nilai & $\begin{array}{c}\text { Freku } \\
\text { ensi }\end{array}$ & $\begin{array}{l}\text { Rata } \\
\text {-rata }\end{array}$ & Nilai & $\begin{array}{c}\text { Freku } \\
\text { ensi }\end{array}$ & $\begin{array}{l}\text { Rata- } \\
\text { rata }\end{array}$ \\
\hline 40 & 3 & \multirow{7}{*}{$\begin{array}{c}65,0 \\
0\end{array}$} & 30 & 2 & \multirow{7}{*}{57,94} \\
\hline 50 & 6 & & 40 & 2 & \\
\hline 55 & 2 & & 50 & 7 & \\
\hline 60 & 3 & & 55 & 6 & \\
\hline 65 & 1 & & 60 & 7 & \\
\hline 70 & 10 & & 70 & 4 & \\
\hline 75 & 6 & & 75 & 6 & \\
\hline
\end{tabular}

\begin{tabular}{|c|c|c|c|}
\hline 80 & 6 & & \\
\hline Jumlah & 37 & Jumlah & 34 \\
\hline
\end{tabular}

Hasil penelitian menunjukkan bahwa ada pengaruh yang signifikan menggunakan model pembelajaran inkuiri terbimbing terhadap hasil belajar fisika pada materi pokok listrik dinamis di kelas $\mathrm{X}$ semester II SMA Negeri 14 Medan T.P. 2014/2015.

Hal ini ditunjukkan dengan meningkatnya hasil belajar siswa dari nilai rata-rata pretes kelas eksperimen sebesar 42,02 dan tidak ada seorang pun siswa yang mencapai KKM sebesar 75 menjadi sebesar 65,00 pada nilai rata-rata postes dengan jumlah siswa yang mencapai KKM sebanyak 12 orang dari 37 orang siswa.

Hasil penelitian terhadap kelas kontrol dengan menggunakan pembelajaran konvensional terhadap hasil belajar siswa pada materi pokok listrik dinamis di kelas X semester II SMA negeri 14 Medan T.P. 2014/2015 juga menunjukkan adanya peningkatan hasil belajar. Hal ini ditunjukkan dengan meningkatnya hasil belajar siswa dari nilai rata-rata pretes kelas kontrol sebesar 39,85 dan tidak ada seorang pun siswa yang mencapai KKM sebesar 75 menjadi sebesar 57,94 pada nilai rata-rata postes dengan jumlah siswa yang mencapai KKM sebanyak 6 orang dari 34 orang siswa.

Berdasarkan uraian di atas, maka hasil penelitian ini menunjukkan adanya perbedaan model pembelajaran inkuiri terbimbing dengan pembelajaran konvensional terhadap hasil belajar siswa pada materi pokok listrik dinamis di kelas X semester II SMA negeri 14 Medan T.P. 2014/2015. Adanya perbedaan hasil belajar yang signifikan antara kelas ekperimen dan kelas kontrol disebabkan oleh penggunaan model pembelajaran inkuiri terbimbing pada kelas eksperimen. Model pembelajaran inkuiri terbimbing yang memiliki 
sintaks-sintaks atau fase-fase dalam pembelajaran yang tidak dimiliki oleh pembelajaran konvensional. Model pembelajaran inkuiri terbimbingini menekankan kepada proses keterlibatan siswa secara penuh untuk dapat menemukan materi yang dipelajari dan menghubungkannya dengan situasi kehidupan nyata sehingga mendorong siswa untuk dapat menerapkannya dalam kehidupan sehari-hari, dalam proses pembelajaran inkuiri terbimbing siswa tidak hanya berperan sebagai penerima pelajaran melalui penjelasan guru secara verbal, tetapi siswa berperan untuk menemukan sendiri inti dari materi pelajaran. Keterampilan siswa dalam pembelajaran dengan menggunakan model inkuiri terbimbing merupakan suatu proses yang bermula dari tahap eksplorasi, identifikasi, pembentukan konsep, aplikasi dan evaluasi. Langkahlangkah pembelajaran tersebut mendorong siswa untuk lebih aktif di dalam kelas.

Hasil penelitian ini juga sesuai dengan hasil penelitian yang telah dilakukan oleh beberapa peneliti sebelumnya. Sofiani (2011) menyatakan bahwa model inkuiri terbimbing berpengaruh terhadap hasil belajar fisika siswa pada konsep listrik dinamis. Pengaruh tersebut terlihat dari peningkatan rata-rata hasil belajar siswa pada kelompok eksperimen dibandingkan dengan kelompok kontrol. Nilai rata-rata hasil belajar kelas eksperimen 70,37 dan nilai ratarata hasil belajar kelas kontrol 61,43. Daulay (2014) juga menyatakan aktivitas siswa dikategorikan aktif sejalan dengan peningkatan hasil belajar siswa pada kelas eksperimen. Nilai rata-rata hasil belajar kelas eksperimen 76,25 dan nilai rata-rata hasil belajar kelas kontrol 64,00. Sehingga adanya perbedaan hasil belajar siswa yang signifikan akibat pengaruh penerapan model pembelajaran inkuiri terbimbing. Blanchard dan Southerland (2010) menyatakan bahwa tes hasil belajar siswa dengan inkuiri terbimbing lebih baik dari siswa yang diajar dengan pembelajaran tradisional (konvensional). Model pembalajaran inkuiri terbimbing mempengaruhi tingkat keterampilan dan hasil belajar siswa. Inkuiri terbimbing memberikan arah yang lebih dalam pada saat proses pembelajaran terutama dalam penyelidikan yang dilakukan.

Sama halnya dengan beberapa penelitian diatas, Kulhthau, dkk (2007:6) juga menyatakan bahwa model pembelajaran inkuiri terbimbing memiliki keuntungan bagi siswa yaitu mengembangkan kemampuan sosial, membaca dan keterampilan berbahasa siswa, membangun pemahaman mereka sendiri mengenai hal mereka selidiki, siswa bebas dalam meneliti dan belajar, serta memiliki keterlibatan secara langsung.

\section{KESIMPULAN DAN SARAN}

Dari hasil analisis yang dilakukan dalam penelitian ini diperoleh kesimpulan nilai rata-rata pretes kelas eksperimensebesar 42,02dan nilai ratarata postes pada kelas eksperimen yang diajarkan dengan model pembelajaran inkuiri terbimbing sebesar 65,00. Sedangkan nilai rata-rata pretes kelas kontrolsebesar 39,85 dan nilai rata-rata postes pada kelas kontrol yang diajarkan dengan model pembelajaran konvensional sebesar 57,94. Hasil uji hipotesis memberikan nilai thitung $=2,39$ dan $t_{\text {tabel }}=1,67$, maka $t_{\text {hitung }}>t_{\text {tabel, }}$, menunjukkan bahwa model pembelajaran inkuiri terbimbing memberikan pengaruh yang signifikan daripada pembelajaran konvensional dalam meningkatkan hasil belajar siswa pada materi pokok listrik dinamis di kelas X semester II SMA Negeri 14 Medan T.P 2014/2015. 
Berdasarkan hasil dan kesimpulan dalam penelitian ini, maka peneliti mempunyai beberapa saranbagi pihak yang ingin menerapkan model ini selanjutnya, yaitu :

1. Menyampaikan fenomena yang lebih nyata kepada siswa.

2. Terlebih dahulu mengajarkan penggunaan alat-alat laboratorium yang akan digunakan sehingga tidak menghambat proses pembelajaran pada fase pemahaman konsep yang membutuhkan banyak waktu.

3. Menerapkan model pembelajaran inkuiri terbimbing menggunakan media yang lebih variatif seperti macromedia flash agar hasil yang diperoleh lebih maksimal.

\section{DAFTAR PUSTAKA}

Blanchard, M.R., dan Southerland S.A., (2010), Is Inquiry Possible in Light of Accountability?: A Quantitative Comparison of the Relative Effectiveness of Guided Inquiry and Verification Laboratory Instruction, http://www.kadunaweb.com/PhD/6. \%20Working\%20with\%20schools/Bl anchard_2010_Inq\%20versus\%20ac countability.pdf (accessed 3 Agustus 2015)

Daulay,L., (2014), Pengaruh Model Pembelajaran Inkuiri Terbimbing Terhadap Hasil Belajar Siswa pada Materi Pokok Zat dan Wujudnya di Kelas VII Semester I SMP Negeri 13 Medan T.P. 2013/2014, Skripsi, FMIPA Unimed, Medan.

Hosnan, M,. (2014), Pendekatan Saintifik dan Kontekstual dalam Pembelajaran Abad 21, Penerbit Ghalia Indonesia, Bogor.

Jatmiko, B., dan Puspita, A.T., (2013), Implementasi Model Pembelajaran Inkuiri Terbimbing (Guided Inquiry) Terhadap Keterampilan Berpikir Kritis Siswa pada Pembelajaran Fisika Materi Fluida Statis kelas XI di SMA Negeri 2
Sidoarjo, Jurnal Inovasi Pendidikan Fisika, Vol.02 No.03 : 121-125.

Kuhlthau, C.C., Maniotes, L.K., dan Caspari, A.K., (2007), Guided Inquiry :Learning in 21st Century School, Greenwood Publishing Group, USA.

Kuhlthau, C.C., Maniotes, L.K., dan Caspari, A.K., (2012), Guided Inquiry Design : a framework fo inquiry in your school, ebook: www.abc.clio.com, California.

Kurniawati, I.D., Wartono, dan Diantoro, M., (2014), Pengaruh Pembelajaran Inkuiri Terbimbing Integrasi Peer Instruction Terhadap Penguasaan Konsep dan Kemampuan Berpikir Kritis Siswa, Jurnal Pendidikan Fisika Indonesia, Vol 10 No 1: 36-46.

Sofiani E., (2011), Pengaruh Model Inkuiri terbimbing (Guided Inquiry) Terhadap Hasil Belajar Fisika Siswa pada Konsep Listrik Dinamis, Skripsi, FMIPA UIN Syarif Hidayatullah, Jakarta.

Sudibyo, M.I., dan Supardi, Z.A.I., (2013), Profil Konsep Hukum Newton dan Kecakapan Berpikir Kritis Mahasiswa Angkatan 2012 Kelas Internasional Prodi Pendidikan Fisika FMIPA Universitas Negeri Surabaya, Jurnal Inovasi Pendidikan Fisika, Vol. 02 No. 03: 38-43.

Wicaksono, S.R., Ferdianto, J., dan Suprapto, E., (2011), Desain Penelitian Menggunakan Quasi Experiment,

http://www.slideshare.net/soetam $/ \mathrm{k}$ uasi-eksperimen (accessed 1 Maret 2015)

Yunus, S.R., Sanjaya, I.G.M., dan Jatmiko, B.,(2013), Implementasi Pebelajaran Fisika Berbasis Guided Inquiry untuk Meningkatkan Hasil Belajar Siswa Auditorik, Jurnal Pendidikan IPA Indonesia, Vol. 2 No. $1: 48-52$ 